\title{
RESENHA DE POR LINHAS TORTAS: ANÁLISE DE QUINCAS BORBA \\ DE MACHADO DE ASSIS, DE PAUL DIXON
}

\section{REVIEW OF POR LINHAS TORTAS: ANÁLISE DE QUINCAS BORBA DE MACHADO DE ASSIS, BY PAUL DIXON}

DIXON, Paul. Por linhas tortas: análise de Quincas Borba de Machado de Assis. São Paulo: Nankin, 2020. 184p.

\section{JEAN PIERRE CHAUVIN}

Universidade de São Paulo

São Paulo, São Paulo, Brasil

$\mathrm{P}$ aul Dixon é bastante conhecido entre nós: há mais de trinta anos, ele se dedica à pesquisa sobre literatura brasileira. Em sua extensa e variada produção, sobressaem numerosos artigos de fôlego sobre Machado. Esse dado é importante porque, onze anos após sair O chocalho de Brás Cubas, somos contemplados com a publicação de Por linhas tortas: análise de Quincas Borba de Machado de Assis. No livro anterior, o crítico assinalava que "assim como o menino é gerador do homem, o momento do chocalho é gerador de todo o texto" (DIXON, 2009, p. 15). Proposta abrangente, tratava-se de uma leitura que levava em conta os níveis temático, estrutural e discursivo do romance.

A abrangência persiste, mas, embora possamos vislumbrar diversos pontos de contato entre um ensaio e outro, as perspectivas de leitura são um pouco diferentes. Desta feita, Paul Dixon enfatiza os preceitos da fenomenologia (de Levinas a Merleau-Ponty), enquanto escrutina numerosos episódios do Quincas Borba, sobremodo atento aos meneios do narrador e à caracterização e atuação das personagens, sujeitas a fatores que as desviam de sua rota. Trata-se de examinar minuciosamente os elementos que interferem (e se refletem) na maneira como as figuras machadianas pensam, sentem e agem. Que elementos? Podem ser pessoas, mas também roupas, carruagens, janelas e paisagens. Quase tudo e todos postos em movimento, a contrapor "vencedores" e "vencidos", segundo a lógica aparentemente sem arestas do pragmatismo. 
Para Dixon, seria fundamental que o narrador extradiegético de Quincas $B o r b a$ - embora situado entre dois romances enunciados em primeira pessoa - não fosse visto como um "retrocesso" do método criativo, refletido no modo machadiano de narrar. Por sinal, ele nos convence justamente do contrário: trata-se de um romance que conta com um "enunciador agressivo, cínico e muito menos amigo do leitor" (DIXON, 2020, p. 38), cuja leitura completa e é complementada pela obra anterior.

Nesse sentido, as marcas de enunciação em Quincas Borba evocam e amplificam a dicção caprichosa e galhofeira de Brás Cubas, em que a história dos outros também fora colocada sob a perspectiva fria e indiferente de quem as (re)contou. Percebe-se que o ponto de partida do ensaísta são os pensamentos monodimensionais de Rubião - cioso de sua nova condição socioeconômica -, o que sugere uma visão menos compadecida desse protagonista do avesso. Talvez ele seja incapaz de narrar a si mesmo justamente porque lhe faltam os recursos para ser e atuar na corte, como se esperaria:

Rubião entra no trem com seu desejo de batatas cariocas em abundância, com sua sede das águas de validação emocional. Palha entra no mesmo trem, sentindo uma fome diferente e não tão diferente. No início são desejos separados, linhas diretas. Mas o magnetismo social confunde-os, leva-os no caminho das linhas tortas. E Sofia contribui fortemente para tal confusão, criando um triângulo e uma simetria em que o desejo materialista de um corresponde ao desejo amoroso do outro. (DIXON, 2020, p. 24)

Por linhas tortas reforça o caráter tragicômico do romance: Rubião é um ser contraditório e inábil que, deslumbrado com a sua mudança da província ("ontem, professor") para a capital do Império ("hoje, capitalista"), confunde impulso perdulário com generosidade. Relativamente ingênuo, supõe que agir prodigamente com os "amigos" transparecerá como desprendimento material e distinção de classe. Ele é incapaz de perceber as estratégias com que Cristiano Palha, Sofia, Carlos Maria, Freitas e Camacho o seduzem, bajulam ou espoliam, alugando-lhe tão caro o privilégio de sua companhia. Para o leitor, o contraste entre o caráter das personagens e o modo como Rubião as percebe é evidente: "O comensal Freitas é exemplo hiperbólico do parasita" (DIXON, 2020, p. 96).

Mas Dixon vai além. Observa que o ex-professor serve de refeição alimentícia e pecuniária, capaz de saciar a "fome metafórica" de quase todos - 
seja ao receber convidados regularmente, à mesa de sua resplandecente mansão no Botafogo; seja ao se declarar a Sofia, sob as estrelas (as mesmas que continuarão a brilhar indiferentes à sua trajetória entre o fausto e a miséria, quando retornar sem coroa, nem juízo, a Barbacena). Isso também acontece porque "as visitas são o mecanismo social que permite, na fusão do desejo e do espaço, o jogo de oferecer, proteger, invadir, compartilhar ou roubar territórios". Além disso, denunciam a "exagerada generosidade de novo-rico" (DIXON, 2020, p. 75) mal encenada por Rubião.

Segundo Dixon, o fato de a teoria de Humanitas ser desmembrada nas Memórias póstumas e no Quincas Borba reforça a tese de que os romances podem ser apreendidos como contrapartes do mesmo projeto machadiano. De fato, lidas em perspectiva, ambas as narrativas podem ser vistas como pretexto para as elucubrações de Quincas, pois sustentam a doutrina do filósofo: "O bombástico e desequilibrado Quincas Borba está muito bem satirizado no texto, mas sua filosofia fica em pé, porque quase toda a ação do relato acaba sendo a demonstração da eficácia de tal doutrina" (DIXON, 2020, p. 43). Nesse sentido, poderíamos afirmar que em Quincas Borba lemos a autoparódia da doutrina apresentada no romance anterior.

É sugestivo que o discurso amalucado de Quincas seduza tanto o burguês de nascença, que é Brás, quanto o novo-rico, que é Rubião. Contudo, os efeitos são bem diferentes. Para Brás Cubas, o discurso de Quincas resulta inócuo: é fruto da extravagância de um lunático. Rubião não está na mesma condição social do primeiro, nem possui estrutura mental capaz de discernir a canastrice generalizada. Brás leva uma vida financeiramente folgada, sem possibilidade de legar seus bens ao filho perdido; Rubião herda a fortuna e a demência do filósofo a quem serviu de enfermeiro.

Para o ex-professor de Barbacena, a doutrina explicaria o êxito: ter se tornado "capitalista". Embora ele não se dê conta, o leitor desconfia, desde as primeiras linhas, que o saldo de Rubião resulta ainda mais negativo que a miséria reivindicada por Brás Cubas: "Com o tempo, os almoços e jantares na casa de Rubião chegam a ser uma confirmação emblemática das duas tribos famintas. Como se verá, não há suficientes 'batatas' para todos, e as de Rubião acabarão sendo dos outros" (DIXON, 2020, p. 91).

No entanto, a metáfora da intersubjetividade não se resume ao enredo. Afinal, Machado também teria se alimentado de outras vozes e romances, ao compor o seu: "Em vez de seguir direto para seu destino, o texto machadiano passeia, parando para reconhecer e dialogar com seus colegas e amigos literários" (DIXON, 2020, p. 27), de Luciano de Samósata a Laurence Sterne, 
passando por Erasmo de Roterdã e Miguel de Cervantes. "Dom Quixote é um livro de segundo grau, pois imita, satiricamente, um modelo de livro anterior, o gênero dos romances de cavalaria", enquanto "Quincas Borba se apresenta como um livro de terceiro grau, ao dar-nos a figura de um protagonista que imita Dom Quixote" (DIXON, 2020, p. 57).

Outro fator crucial, assinalado por Paul Dixon: a quase invisibilidade dos escravos em Quincas Borba. Num romance em que os objetos são estratégicos para a economia narrativa, há raras menções às pessoas escravizadas: "se por um lado os personagens do romance parecem estar muito atentos às influências desses elementos não humanos, tratando-os como se fossem gente, pelo outro lado há uma categoria de gente que recebe um tratamento menos que humano" (DIXON, 2020, p. 145, grifo do autor). Crueldade do narrador? Ênfase na sociabilidade dos homens livres? Denúncia da condição a que os escravos continuavam submetidos, durante o Segundo Império?

Dentre outras qualidades do ensaio, Por linhas tortas relembra a importância de fazermos o exame apurado da linguagem. Paul Dixon é um crítico raro, sobremodo atento aos meandros do texto machadiano. Por isso, é capaz de mostrar como determinados temas e artifícios são recorrentes na produção do autor, chamando atenção para o percurso errático e decadente dos "náufragos", em severo contraste com a trajetória reta e ascensional daqueles que souberam coisificar as pessoas e superestimar o valor das coisas, convertendo sujeitos em meros objetos.

\section{Referências}

DIXON, Paul. O chocalho de Brás Cubas: uma leitura das Memórias póstumas. São Paulo: Nankin/Edusp, 2009.

Por linhas tortas: análise de Quincas Borba de Machado de Assis. São Paulo: Nankin, 2020.

JEAN PIERRE CHAUVIN é professor associado do Departamento de Jornalismo e Editoração, na ECA, USP, onde leciona Cultura e Literatura Brasileira. Organizou a coletânea Estudos sobre Dom Casmurro (homenagem a Lineide do Lago Salvador Mosca) (Luva Editora, 2021). (D) https://orcid.org/0000-0001-9514-109X. E-mail: tupiano@usp.br 